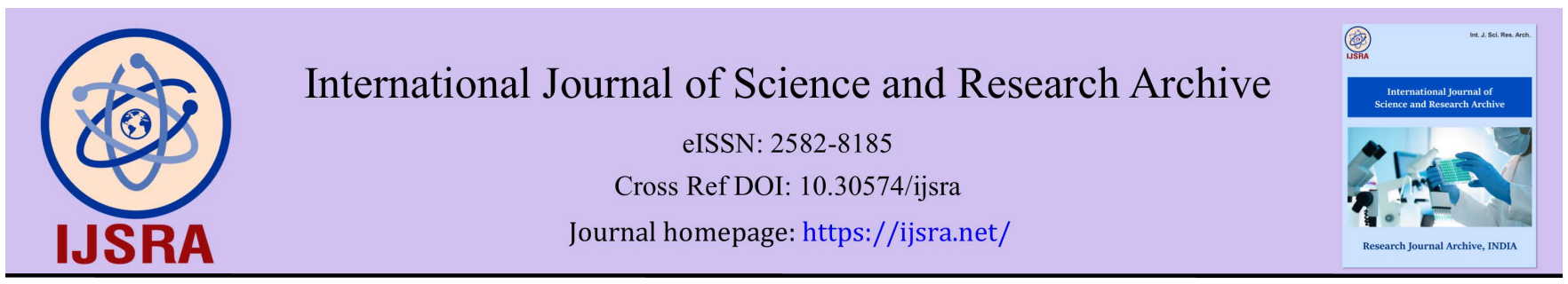

(RESEARCH ARTicle)

\title{
An investigation of the effect of the extracts from the seeds of Bidens pilosa on the growth of Escherichia coli and Bacillus subtilis
}

\author{
Jordan Johnson, Lovely Anderson and Jennifer Laifa* \\ Department of Natural Sciences \& Environmental Health, Mississippi Valley State University, Itta Bena, Mississippi, US, \\ 38941.
}

International Journal of Science and Research Archive, 2021, 04(01), 125-128

Publication history: Received on 30 October 2021; revised on 12 December 2021; accepted on 14 December 2021

Article DOI: https://doi.org/10.30574/ijsra.2021.4.1.0191

\begin{abstract}
Escherichia coli is a Gram-negative bacterium also found in the human. Bacillus subtilis is a Gram-positive, nonpathogenic, endospore-forming bacterium. The spores can survive the heat and $B$. subtilis to cause food poisoning. The study hypothesized that the extracts from B. pilosa would inhibit the growth of E. coli and B. subtilis. The seeds of $B$. pilosa were purchased from the seed company. The seeds were dried, ground, and shaken in acetone, ethanol, methanol, and water for 72 hours. Solvents were evaporated and the crude extracts were used for antibacterial activity using a modified Kirby-Bauer disc method. The results revealed that the growth of E. coli was inhibited by the extracts using ethanol. The zones of inhibition were $13 \mathrm{~mm}$. The extracts that were extracted using acetone and water were not effective in inhibiting the growth of E. coli. The growth of B. subtilis was inhibited by the extracts from acetone and methanol. The zones of inhibition were $13 \mathrm{~mm}$. The results revealed that the extracts from ethanol and water were not effective in inhibiting the growth of $B$. subtilis. Seeds of $B$. pilosa have the potential to be used as antimicrobials.
\end{abstract}

Keywords: Antimicrobial; Bidens pilosa; Zone of inhibition; Kirby-Bauer disc method; Escherichia coli; Bacillus subtilis

\section{Introduction}

In 2013, the Centers for Disease Control and Prevention (CDC) released a report on the threats by antibiotic threats. According to the report, antibiotic-resistant bacteria can cause illnesses and death as at least 2 million get infections and 23,00 die each year from the bacteria that are resistant to the antibiotics (U.S. Department of Health and Human Services, Centers for Disease Control and Prevention, 2013) [1]. This prompted the White House to come up with a national strategy to the threat (The White House, Office of the Press Secretary, 2014) [2]. According to the order that was released by President Obama in 2014, combating antibiotic-resistant bacteria was to be treated as a national security priority. A 2019 report from the CDC (U.S. Department of Health and Human Services, Centers for Disease Control and Prevention, 2019) [3], an estimate of 2,868,700 infections, and 35,900 deaths occur each year from antibiotic-resistant bacteria.

One of the organisms that are resistant to antimicrobials is Escherichia coli which has been an organism of interest in the present study. E. coli is a Gram-negative bacterium found harmless in the human. Although it is harmless, several studies have shown that the antimicrobial-resistant $E$. coli can cause harm in adult humans by causing urinary tract infections (Shah, et al. 2020; Selim et al. 2019) [4, 5] suggesting that during sexual intercourse due to the closeness of the vagina, urethra, and the anus, there is a possibility that E. coli can travel to the urethra, improper cleaning from back to front and holding the urine, and enlarged prostate gland are to blame for such infections. The harm of antimicrobialresistant E. coli can also be observed in children with diarrhea (Omalajaiya, Afolabi, \& Iweriebor 2020; Shahraki Zahedani, and Sayadzani 2018; Singh et al. 2019) [6, 7, 8]. The antibiotic-resistant E. coli had been found in food such as

\footnotetext{
* Corresponding author: Jennifer Laifa

Department of Natural Sciences \& Environmental Health, Mississippi Valley State University, Itta Bena, Mississippi, US, 38941.

Copyright (C) 2021 Author(s) retain the copyright of this article. This article is published under the terms of the Creative Commons Attribution Liscense 4.0.
} 
meat (Farhoumand et al. 2020) [9], and cheese (Hamzeh Pour, Vaziri, and Molaee Aghaee, 2019) [10]. Antibioticresistant E. coli can also be found in animals (Handrova, and Kmet 2019) [11], and in avian fertilizer (Agostinho et al. 2020) [12]. Seeing that antimicrobial-resistant E. coli is found everywhere in the environment, it is easy for it to be cycling around being transferred among biotic and non-biotic factors in the environment. Although not on the list of organisms that are resistant to antimicrobials, Bacillus subtilis has also been investigated in the present study. B. subtilis is a Gram-positive endospore-forming bacterium generally recognized as safe (U.S. Food Drug Administration 2019) [13]. The spores and the formation of biofilm can cause B. subtilis to be antibiotic-resistant causing food poisoning (Zhang et al. 2019) [14]. Chang et al. (2017) [15] found out that B. subtilis can form biofilm on treated waste heat pump systems.

Plant organs are used around the World as antimicrobials. For the current study seeds of Bidens pilosa have been investigated for the potential as antimicrobial. Bidens pilosa is an annual commonly known as beggarticks, burmarigold, and Spanish needle, that belongs to Asteraceae and has been introduced to the US (USDA, Natural Resources Conservation Service nd) [16].

Most of the research has been done on the effectiveness of B. pilosa using the roots, stems, leaves, and flowers as the antimicrobial but no studies have investigated the effectiveness of the seeds considering that the seeds are easily found as they can easily attach to the clothes. The objective of the study was to investigate whether the extract from the seeds of B. pilosa can inhibit the growth of E. coli and B. subtilis. An investigation was further done on which solvent to choose for extraction of the seeds from the water, acetone, ethanol, or methanol.

\section{Material and methods}

\subsection{Extraction of plant materials}

The seeds of B. pilosa were dried and ground to a homogeneous form using mortar and pestle. Sets of ground seeds were soaked in acetone. Another set of ground seeds were soaked in distilled water. The same procedure was carried out for ethanol and methanol. The seeds were soaked for 72 hours. The concentrations were reduced on all extracts. The extracts were stored for further analysis.

\subsection{Antimicrobial screening}

The plant extracts were tested against the bacterial strain. Using the modified Kirby-Bauer disc method, a test using a 6 $\mathrm{mm}$ filter paper disc with plant crude extracts was performed. E. coli and B. subtilis were transferred on Petri dishes containing agar using a swab saturated with bacteria (Anderson et al., 2019) [17]. Six discs with different plant extracts were dispensed and lightly pressed onto the agar surface swabbed with bacterial strain. The agar plates each swabbed with B. subtilis or E. coli were placed in the incubator for 24 hours at $37^{\circ} \mathrm{C}$. The procedure was carried out in four replicates. Results were recorded after the duration of incubation. Clear zones around the discs with plant extracts were measured (Anderson et al., 2019) [17]. The zones of inhibition were interpreted as resistant, susceptible, and intermediate (Anderson et al., 2019) [17].

\section{Results}

B. pilosa extracted with water did not inhibit the growth of either B. subtilis or E. coli (Figure 1). From the results $B$. pilosa extracted with ethanol did not inhibit the growth of $B$. subtilis whilst the growth of $E$. coli was inhibited. The average zone of inhibition using $B$. pilosa extracted with acetone was $12.5 \mathrm{~mm}$ (Figure 1 ). The average zones of inhibition using B. pilosa extracted with methanol for B. subtilis and E. coli were $13.25 \mathrm{~mm}$ and $9.67 \mathrm{~mm}$, respectively.

\section{Discussion}

In all the studies that have been identified so far, the researchers are either utilizing the leaves or the whole plant body of $B$. pilosa to investigate the effect of the plant as an antimicrobial agent. The present study is one of the few studies where seeds are used to investigate the effect of the extracts of the seeds as antimicrobials.

The studies on the use of B. pilosa as antimicrobials have revealed that B. pilosa can be depending on the organ used, inhibit the growth of microorganisms, or show no activity at all. Leaves of B. pilosa have been used by Mabeku, Bille, and Nguepi (2016) [18] on methanol and ethyl acetate where they were using the Helicobacter pylori. They have found out that B. pilosa was not effective in inhibiting H. pylori. Using the essential oils from the roots of B. pilosa there was no activity against the Gram-negative bacterial cells (Verma et al. 2016) [19]. Using botanical material, Chiavari-Frederico 
et al. (2020) [20], found that E. coli was not susceptible to B. pilosa. Ashafa and Afolayan (2009) [21], found out that root extracts from B. pilosa using acetone and methanol, inhibited the growth of $E$. coli but not the extracts using hot water. Njume et al. (2016) [22], used the whole plants; the roots, stems, leaves, and flowers, and revealed that the plant extracted using water did not inhibit $E$. coli, with inhibition by the acetone, ethanol, and methanol at $10 \mathrm{~mm}, 11 \mathrm{~mm}$, and $11 \mathrm{~mm}$, respectively. When using the leaves of B. pilosa, Adedapo, Jimoh, and Afolayan (2011) [23] found out that the growth of $E$. coli can be inhibited by the extracts using acetone, methanol but not water. So far, all the research reports have indicated that water is not a suitable solvent for the extraction of B. pilosa. The same trend has been observed in the present study. The solvent of choice in extracting B. pilosa can be assumed to either be methanol, ethanol, or acetone as has been displayed from the present study and other studies available to date.

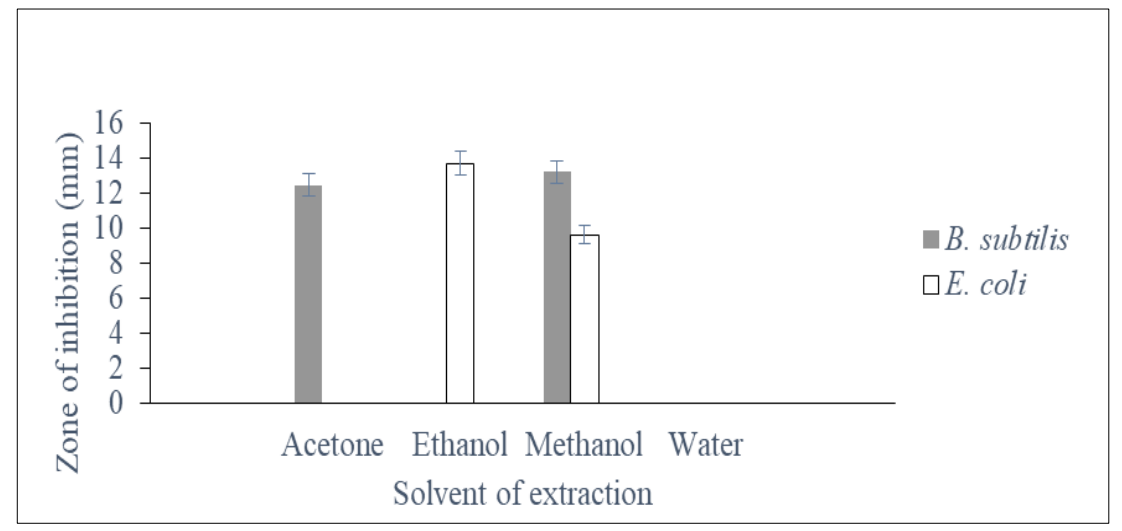

Figure 1 Zones of inhibition (mm) on B. subtilis and E. coil. grown in the presence of extracts from B. pilosa

\section{Conclusion}

The seeds of B. pilosa can also be used as antimicrobials in inhibiting the growth of E. coli and B. subtilis.

\section{Compliance with ethical standards}

\section{Acknowledgments}

The authors would like to acknowledge the Department of Natural Sciences and Environmental Health Mississippi Valley State University where the study was conducted. Funding for the study was provided by Minority Science and Engineering Improvement Program (MSEIP) P120A170085, STEM CHANGERS Mississippi Valley State University.

\section{Disclosure of conflict of interest}

There are no conflicts of interest to be disclosed by the authors.

\section{Statement of ethical approval}

The present research work does not contain any studies performed on animals / human subjects by any of the authors.

\section{References}

[1] US. Department of Health and Human Services, Centers for Disease Control and Prevention [Internet]. Antibiotic resistance threats in the United States [cited 2013].

[2] Obama B. The White House, Executive Order - Combating antibiotic resistant bacteria [Internet]. Washington, D.C.: Office of the Press Secretary [cited 2014].

[3] Redfield RR. US. Department of Health and Human Services, Centers for Disease Control and Prevention [Internet]. Antibiotic resistance threats in the United States [cited 2019].

[4] Shah TA, Preethishree P, Ashwini, Pai V. Bacterial profile of urinary tract infections: evaluation of biofilm formation and antibiotic resistance pattern of uropathogenic Escherichia coli. Journal of Pure Applied Microbiology. 2020 Dec; 14(4): 2577-2584. 
[5] Selim S, Abdel Aziz MH, El-Alfay SM, Zakaria H. Incidence and antibiotics resistance of Staphylococci and Escherichia coli isolated from diabetic urinary tract infection patients in Egypt. Journal of Pure Applied Microbiology. 2019 Sep; 13(3): 1697-1702.

[6] Omalajaiye SA, Afolabi KO, and Iweriebor BC. Pathotyping and antibiotic resistance profiling of Escherichia coli isolates from children with acute diarrhea in Amatole district municipality of Eastern Cape, South Africa. Hindawi BioMed Research International. Nov 2020; 1-10.

[7] Zahedani SS, Sayadzai N. Frequency and antibiotic resistance pattern of diarrheagenic Escherichia coli (DEC) strains isolated from children aged less than 10 years. Medical Laboratory Journal. 2018 Mar-Apr; 12(2): 7-12.

[8] Singh T, Singh PK, Dar SA, Haque S, Akhter N, Das S. Changing paradigm of antibiotic resistance amongst Escherichia coli isolates in Indian pediatric population. PLoS ONE. Apr 2019; 14(4): e0213850.

[9] Farhoumand P, Hassanzandazar H, Soltanpour MS, Aminzare M, Abbasi Z. Prevalence, genotyping and antibiotic resistance of Listeria monocytogenes and Escherichia coli in fresh beef and chicken meats marketed in Zanjan, Iran. Iranian Journal of Microbiology. Dec 2020; 12(6): 537-546.

[10] Hamzeh Pour S, Vaziri S, Molaee Aghaee E. Survey on the contamination rate and determination of antibiotic resistance of Staphylococcus aureus, Escherichia coli and Salmonella strains isolated from traditional cheeses distributed in Mahabad, Iran. Iranian Journal of Health and Environment. Mar 2019; 11(4): 465-476.

[11] Handrova L, Kmet V. Antibiotic resistance and virulence factors of Escherichia coli from eagles and goshawks. Journal of Environmental Science and Health, Part B. May 2019; 54(7): 605-614.

[12] Agostinho JMA, Cardozo MV, Borzi MM, Marin JM. Antibiotic resistance and virulence factors among Escherichia coli isolates from avian organic fertilizer. Ciência Rural, Santa Maria. 2020; 50(2): e20180849.

[13] Medicinal Botany US Forest Service United States Department of Agriculture [Internet]. Celebrating Wildlife [cited 2021].

[14] Zhang QQ, Zhang YH, Cai FY, Liu XL, Chen XH, Jiang M. Comparative antibacterial and antibiofilm activities of garlic extracts, nisin, $\varepsilon$-polylysine, and citric acid on Bacillus subtilis. Journal of Food Processing and Preservation. Sep 2019; 43(11): e14179.

[15] Chang S, Chen X, Jiang S, Chen J, Shi L. Using micro-patterned surfaces to inhibit settlement and biofilm formation by Bacillus subtilis Journal of Microbiology. Jul 2017; 63(7): 608-620.

[16] USDA Natural Resources Conservation Service Bidens pilosa hairy beggarticks [Internet]. United States Department of Agriculture. 2021.

[17] Anderson DG, Salm SN, Allen DP, Nester EW. Nester's Microbiology A Human Perspective, Ninth Edition, New York, NY: McGraw Hill. 2019.

[18] Mabeku LBK, Bille BE, Nguepi E. In vitro and in vivo anti-helicobacter activities of Eryngium foetidum (Apiaceae), Bidens pilosa (Asteraceae), and Galinsoga ciliata (Asteraceae) against Helicobacter pylori. BioMed Research International. Aug 2016; 1-7.

[19] Verma RS, Padalia RC, Goswami P, Verma SK, Chauhan A, Darokar MP. Chemical composition and antibacterial activity of Bidens pilosa. Chemistry of Natural Compounds. Mar 2016; 52(2): 340-341.

[20] Chiavari-Frederico MO, Barbosa LN, Carvalho dos Santos I, Ratti da Silva G, Fernandes de Castro A, de Campos Bortolucci W. Antimicrobial activity of Asteraceae species against bacterial pathogens isolated from postmenopausal women. PLoS ONE. Jan 2020; 15(1): 1-14.

[21] Ashafa AOT, Afolayan AJ. Screening the root extracts from Biden pilosa L. var. radiata (Asteraceae) for antimicrobial potentials. Journal of Medicinal Plants Research. Jul 2009; 3(8): 568-572.

[22] Njume C, Gqaza B, Rozani C, Goduka NI. Studies on bioactivity and secondary metabolites of crude extracts of Bidens pilosa L. (Asteraceae): A medicinal plant used in the Transkei region of South Africa. Pakistan Journal of Pharmaceutical Sciences. May 2016; 29(3): 877-885.

[23] Adeolu A, Jimoh F, Afolayan A. Comparison of the nutritive value and biological activities of the acetone, methanol and water extracts of the leaves of Bidens pilosa and Chenopodium album. Acta Poloniae Pharmaceutica-Drug Research. Jan-Feb 2011; 68(1): 83-92. 